九州大学学術情報リポジトリ

Kyushu University Institutional Repository

\title{
Establishment of the Optimal Conditions for Two-Dimensional Gel Electrophoresis of Papaya Seed Proteome
}

\section{Roan, Su-Feng}

Department of Horticulture and Biotechnology, Chinese Culture University

Hsiung, Tung-Chuan

Department of Horticulture and Biotechnology, Chinese Culture University

Yang, Kai-Yun

Department of Horticulture and Landscape Architecture, National Taiwan University

Liu, Wei-Ting

Department of Horticulture and Landscape Architecture, National Taiwan University

他

https://doi.org/10.5109/27353

出版情報: 九州大学大学院農学研究院紀要. 58 (2)，pp.239-246，2013-09. Faculty of Agriculture， Kyushu University

バージョン :

権利関係 : 


\title{
Establishment of the Optimal Conditions for Two-Dimensional Gel Electrophoresis of Papaya Seed Proteome
}

\section{Su-Feng ROAN ${ }^{1}$, Tung-Chuan HSIUNG ${ }^{1}$, Kai-Yun YANG ${ }^{2}$, Wei-Ting LIU' ${ }^{2}$, Ing-Feng CHANG ${ }^{3}$, Chun-Ta WU'* and Akira WAKANA}

\author{
Laboratory of Horticultural Science, Division of Agronomy and Environmental Science, \\ Department of Agro-environmental Sciences, Faculty of Agriculture, \\ Kyushu University, Fukuoka 812-8581, Japan \\ (Received April 12, 2013 and accepted May 16, 2013)
}

\begin{abstract}
Papaya seeds are considered as a recalcitrant material for protein preparation in two-dimensional gel electrophoresis (2-DE) because of abundance of interfering compounds. We examined two protein extraction methods, the classical trichloroacetic acid (TCA) / acetone precipitation (TCA-A) and phenol ammonium acetate-methanol precipitation ( $\mathrm{P}-\mathrm{AA}-\mathrm{M})$ methods, to evaluate their compatibility and efficiency of extracting papaya seed proteins in SDS-PAGE and two-dimensional (2D) gel electrophoresis analysis. Compared with TCA-A method, P-AA-M method showed better results, i.e., it increased at least five distinguished bands in SDS-PAGE, reduced problems of streaking and smearing in 2D gel, and enhanced resolution of detectable spots from $124 \pm 27$ to $717 \pm 32$. Comparison between traditional Coomassie Brilliant Blue R-250 staining and zinc-reverse staining was also conducted. The result showed that seven times more protein spots could be identified from 2D gel stained with zinc-reverse stain procedure. The resolution of $2 \mathrm{D}$ gel analysis for papaya seed proteome was further improved by utilizing $\mathrm{pH}$ 4-7 isoelectric focusing gel instead of $\mathrm{pH}$ 3-10 one. The protein spots picked from 2D gel through the protocol that we established were compatible with identification assessments of LC-MS/MS. Our data will serve as a platform and reference for future research in proteomics of papaya seeds or other recalcitrant plant materials.
\end{abstract}

Key words: papaya seed, protein extraction, proteomics, two dimensional gel electrophoresis, zinc-reverse stain

\section{INTRODUCTION}

In proteomics research, a crucial step to obtain high resolution of the protein profile is to improve the quality of protein sample preparation (Görg et al., 2000). Usually, plant tissues, unlike bacterial and animal cells, are rich in carbohydrates, organic acids, proteolytic and oxidative enzymes, and secondary metabolites such as pigments, phenolic compounds, and terpenes, which often interfere the resolution of protein separation on two-dimensional (2D) gel electrophoresis. For example, the high levels of secondary metabolites in distinct developmental stages, such as leaf senescence or fruit maturation, have strongly affected protein extraction and, as a consequence, interfered with the results of the $2 \mathrm{D}$ gel electrophoresis analysis with horizontal and vertical stripes, viz. streaking and smearing, as well as decrease in the resolution of the protein spots (Saravanan and Rose, 2004).

Typical method used for extracting plant proteins is grinding the plant tissue in liquid nitrogen in extraction buffer, followed by trichloroacetic acid (TCA) / acetone precipitation (Carpentier et al., 2005). For woody plants and other plant tissues that are rich in polyphenol, the extraction by phenol is recommended because

\footnotetext{
1 Department of Horticulture and Biotechnology, Chinese Culture University, Taipei, Taiwan

Department of Horticulture and Landscape Architecture, National Taiwan University, Taipei, Taiwan

Institute of Plant Biology, National Taiwan University, Taipei, Taiwan

* Corresponding author (E-mail: wuct@ntu.edu.tw)
}

the hydroxyl (OH-based) and protein-hydrophilic functional group of phenol could be used to separate the protein and the interfering substances within the tissue (Mijnsbrugge et al., 2000; Wang et al., 2003). The earliest phenol extraction was done by Hurkman and Tanaka (1986); the ammonium acetate / methanol solution was further used for protein precipitation prior to increase the number of protein spots and resolution on $2 \mathrm{D}$ gel electrophoresis.

Papaya (Carica papaya L.), an herbaceous perennial fruit crop belonging to the family Caricaceae, is commercially cultivated throughout the tropics and in many subtropical regions of the world. In the past decade, the global production, market demand, and international trade in papaya fruit have shown buoyant growth (Singh 2011). Unlike that most of fruit crops are propagated vegetatively, the propagule of papaya in commercial cultivation almost entirely depends on seeds (Paull and Duarte, 2011). Seed dormancy has long been an obstacle for the reproductive propagation in papaya; therefore, both illustration of the germination biology and establishment of the technologies for dormancy breakage have been extensively explored (Andreoli and Khan, 1993; Bhattacharya and Khuspe, 2001; Chacko and Singh, 1966; Salomao and Mundim, 2000; Wood et al., 2000).

Proteomics has been widely adopted in the research of biology, medicine, and agriculture in recent years largely due to the advances in mass spectrometry and methodology development (Miernyk and Hajduch, 2011). Two-dimensional-gel basis proteomics has also been utilized in seed biology field to provide an overview of 
protein dynamics during seed development and germination as well as to elucidate the molecular mechanisms of postharvest treatments for the effects of seed vigor and longevity (Gallardo et al., 2001; Miernyk and Hajduch, 2011; Pawlowski, 2010). Along with the information from completed genome sequences of various organisms, further understandings in physiological and molecular mechanisms and gene-related reactions can be established as systems in biology scale. The whole papaya sequence was completed in 2008 (Ming et al., 2008), and can be retrieved from NCBI database (http:// www.ncbi.nlm.nih.gov/Taxonomy/Browser/wwwtax. cgi?id=3649) to facilitate the genomics and proteomics research. Indeed, Rodrigues et al. (2009) has published the procedures for sample preparation and 2D gel electrophoresis to study the proteome of papaya leaves. However, the methodology and proteome analysis of papaya seeds has not yet been reported to date.

The objective of this study was to evaluate the quality of protein samples of papaya seeds prepared by two different extraction methods in terms of protein number and resolution of gel profile. Effects of gel staining protocols and $\mathrm{pH}$ gradient ranges of Isoelectric focusing (IEF) electrophoresis on protein separation and detection were also assessed. The results may contribute to facilitating the employment of proteomic approaches for the research of seed biology in papaya.

\section{MATERIALS AND METHODS}

\section{Plant material and seed germination condition}

The papaya seeds utilized in this research were extracted from ripening 'Tainung No.2' papaya fruit. After water floatation to sort out pulp and immature (white) and empty seeds, the arils of heavy and sound seeds sinking to the bottom were removed via scrubbing and washed thoroughly. The papaya seeds were then sterilized in $10 \%$ Chlorex $^{\circledR}$ bleach $(0.6 \%$ sodium hypochlorite) and 1\% Tween 20 solution with sonication for 5 minutes followed by thoroughly rinsing with distilled water. The seeds were dried in an air-circulating oven at $36^{\circ} \mathrm{C}$ for $48 \mathrm{hrs}$. The dried seeds (seed water content around $7.93 \pm 0.03 \%$ ) were sealed in plastic bags and stored in a desiccator chamber at $10^{\circ} \mathrm{C}$ until use.

For germination, the papaya seeds were soaked in deionized water at $26^{\circ} \mathrm{C}$ in dark for $24 \mathrm{hrs}$ before sowing 25 seeds on two layers of Advantec No. 3 filter paper in a 9-cm-diameter Petri dish moistened with $10 \mathrm{~mL}$ of deionized water. The seeds were incubated at $26^{\circ} \mathrm{C}$ without light for four days prior to protein extraction. Because of seed dormancy, there was no seed germination after the five-day incubation. Each protein sample replicate was prepared from $2 \mathrm{~g}$ (about 150 seeds) of papaya seeds. All experiments were independently repeated at least three times.

\section{Protein extraction}

Two grams of papaya seeds were grounded in liquid nitrogen with a pre-chilled mortar and pestle and trans- ferred to a tube containing $10 \mathrm{~mL}$ of extraction buffer [20 mM Tris-HCl (pH 7.5), 250 mM sucrose, 10 mM ethylenediaminetetraacetic acid (EDTA), $1 \mathrm{mM}$ dithiothreitol (DTT) and 1\% (v/v) Triton X-100 and 2\% (w/v) of polyvinylpolypyrrolidone (PVPP) (Sigma, USA). After thoroughly vortexed, the sample was homogenized by Polytron for one minute, and then centrifuged at 13,500 g for 15 minutes at $4^{\circ} \mathrm{C}$. The homogenate was filtrated through a layer of Advantec No. 3 filter paper and the filtrate was collected in another centrifuge tube, with addition of PVPP to $2 \%(\mathrm{w} / \mathrm{v})$ and mixed thoroughly. The sample was incubated on ice for 10 minutes and then centrifuged at $13,500 \mathrm{~g}$ for 15 minutes at $4^{\circ} \mathrm{C}$. The supernatant was filtrated through filter papers. The protein samples were then further precipitated by TCA/acetone method or extracted by phenol followed by ammonium acetate/methanol mixture.

\section{TCA/acetone precipitation (TCA-A)}

The trichloroacetic acid (TCA)/acetone precipitation method was adapted from Yang et al. (2007) used for rice seeds with minor modifications and referred as 'TCA-A' in this research. The filtrated protein solution prepared above was mixed with 3x volume of 10\% TCA/ acetone solution followed by overnight precipitation at $-20^{\circ} \mathrm{C}$. After $13,500 \mathrm{~g}$ centrifugation at $4^{\circ} \mathrm{C}$ for $15 \mathrm{~min}-$ utes, the supernatant was removed and the precipitant was washed three times with $80 \%$ and 100\% acetone, respectively. The pellet was dried at room temperature for three minutes.

Phenol extraction, and precipitation with $0.1 \mathrm{M}$ ammonium acetate/methanol mixture $(P-A A-M)$

The P-AA-M method was performed as described in Rodrigues et al. (2009) with modifications. The filtrated protein solution prepared above was mixed with an equal volume of phenol ( $\mathrm{pH} 8.0$ ) for 10 minutes on a vortex, then centrifuged $13,500 \mathrm{~g}$ for 15 minutes at $4^{\circ} \mathrm{C}$. The upper aqueous layer was removed by using a micropipette and $5 \mathrm{x}$ volume of $0.1 \mathrm{M}$ ammonium acetate/methanol mixture was added and precipitated overnight at $-20^{\circ} \mathrm{C}$. After $13,500 \mathrm{~g}$ centrifugation at $4^{\circ} \mathrm{C}$ for $15 \mathrm{~min}$, the upper aqueous layer was removed without touching the white precipitants, which were then washed twice with $10 \mathrm{~mL}$ of $0.1 \mathrm{M}$ ammonium acetate/methanol mixtures followed by twice with $10 \mathrm{~mL}$ of $0.1 \mathrm{M}$ ammonium acetate/80\% methanol mixture. Finally, the precipitant was washed three times with $80 \%$ and $100 \%$ acetone separately to remove excess salts and any interfering substances. The precipitants were dried at room temperature for three minutes.

\section{Protein solubilization and quantitation}

Dried protein samples prepared from Section 2.1 and 2.2 was dissolved with $3 \mathrm{x}$ volume of rehydration buffer containing $7 \mathrm{M}$ urea (Amersham), $2 \mathrm{M}$ thiourea (Merck), 4\% (w/v) CHAPS (Sigma), 60 mM DTT (Sigma) (Görg et al. 1997) at room temperature. Protein concentration was determined by the Bio-Rad protein assay (Bio-Rad, Hercules, CA, USA) according to the manu- 
facturer's instructions. The standard curve was plotted using bovine serum albumin (BSA) (Bio-Rad) as standard.

\section{Sodium dodecyl sulfate polyacrylamide gel elec- trophoresis (SDS-PAGE)}

SDS-PAGE was performed using a 4\% (w/v) acrylamide stacking gel and a $12.5 \%$ (w/v) separation gel according to Laemmli (1970) on SE 400 Sturdier Slab Gel Electrophoresis Units (Hoefer) apparatus. Equal amounts $(50 \mu \mathrm{g})$ of the soluble protein samples were applied to each lane. The electrophoresis was ran with running buffer (25 mM Tris-base, $192 \mathrm{mM}$ glycine, 0.1\% SDS) at $110 \mathrm{~V}$ of constant voltage until the bromophenol blue tracking dye had reached the bottom of the separating gel.

\section{Two-dimensional (2D) gel electrophoresis}

The procedure for 2D gel electrophoresis was performed according the user manual (Bio-Rad or Amersham). An aliquot of $800 \mu \mathrm{g}$ protein sample was mixed with 5\% (v/v) immobilized $\mathrm{pH}$ gradient (IPG)buffer (Bio-Rad) and then rehydration buffer was added to a final volume of $500 \mu \mathrm{L}$. The sample was loaded onto an IPG strip holder with a pre-cast IPG gel $(\mathrm{pH}$ 3-10 or pH 4-7) strip (Bio-Rad) and covered with $2 \mathrm{~mL}$ of mineral oil (Bio-Rad). The holder was placed on the Ettan $^{\mathrm{TM}}$ IPGphorTM 3 IEF System (Amersham) to be rehydrated at $50 \mathrm{~V}$ for $14 \mathrm{~h}$. Isoelectric focusing (IEF) was carried out with $3 \mathrm{~h}$ at $150 \mathrm{~V}, 1 \mathrm{~h}$ at $300 \mathrm{~V}, 1 \mathrm{~h}$ at $600 \mathrm{~V}, 1 \mathrm{~h}$ at $1,200 \mathrm{~V}, 1 \mathrm{~h}$ at 1,200-10,000 V (gradient), and $6 \mathrm{~h}$ at $10,000 \mathrm{~V}$. The IPG gel was then rinsed with distilled water to remove the cover oil. The IPG gel is used for SDS-PAGE directly or stored at $-80^{\circ} \mathrm{C}$ until use within two weeks.

Prior to SDS-PAGE, IPG gel was equilibrated in $5 \mathrm{~mL}$ of SDS equilibration buffer I [6 M urea, $0.375 \mathrm{M}$ Tris-HCl ( $\mathrm{pH}$ 8.8), 2\% SDS, 20\% glycerol, 2\% (w/v) DTT] for 15 minutes with orbital shaking and subsequently for 15 minutes with shaking in $5 \mathrm{~mL}$ of SDS equilibration buffer II [6 M urea, 0.375 M Tris-HCl ( $\mathrm{pH} 8.8$ ), $2 \%$ SDS, $20 \%$ glycerol, $2.5 \%$ (w/v) iodoacetamide]. The separation in the second dimension was realized on the Mini-Trotean (Bio-Rad) or the EttanDALT System (Amersham) with a lab-cast $1.5 \mathrm{~mm}$ SDS polyacrylamide gel (12.5\%) at a current of $45 \mathrm{~mA} \cdot \mathrm{gel}^{-1}$ for $5 \mathrm{hr}$.

\section{Gel staining and image analysis}

2D gel was stained with either zinc-reverse stain method (Fernandez-Patron et al., 1995, 1998) or Coomassie brilliant blue R-250 (CBB) (Neuhoff et al., 1988). For reverse staining, the acrylamide gel was soaked in an equilibration solution $[0.2 \mathrm{M}$ imidazole, $0.1 \%(\mathrm{w} / \mathrm{v}) \mathrm{SDS}$ ] with shaking for 15 minutes and then transferred into a developer solution of $0.3 \mathrm{M}$ zinc sulfate for 30-40 sec with gentle shaking. The stained gel was either scanned immediately or stored in a storage solution of $0.5 \%(\mathrm{w} / \mathrm{v})$ sodium carbonate.

The stained gel image was scanned at a 400 dpi resolution and the gel image analysis and comparison were performed with ImageJ $1.43^{\circledR}$ (National Institutes of Health, USA) software for SDS-PAGE gels and with PDQuest $^{\text {TM }} 8.01$ (Bio-Rad) software for 2 DE gels, respectively.

\section{In-gel digestion and protein identification}

In-gel digestion was conducted as described by Hellman et al. (1995) with modifications. In brief, protein spots of 2-DE gel spots were excised with cut tips and transferred into eppendorf tubes individually. After adding $200 \mu \mathrm{L}$ destain solution [50\% (w/v) acetonitrile, $25 \mathrm{mM}$ ammonium bicarbonate] and incubated at room temperature for 15 minutes, the tube was centrifuged at $10,000 \mathrm{~g}$ for one minute. The destain solution was discarded and the destaining step was repeated until the gel was completely colorless. The gel piece was then covered with $200 \mu \mathrm{L}$ acetonitrile at room temperature for 5 minutes and subsequently centrifuged at 10,000 g for one minute to remove acetonitrile. The sample was allowed to dry for 10 minutes in SpeedVac (Savant). Dehydrated gel particles were incubated in $40 \mu \mathrm{L}$ of $25 \mathrm{mM}$ ammonium bicarbonate with $100 \mathrm{ng}$ trypsin (Sigma) at $37^{\circ} \mathrm{C}$ for at least $16 \mathrm{~h}$. After proteolysis, $50 \mu \mathrm{L}$ elution solution $[50 \%(\mathrm{w} / \mathrm{v})$ acetonitrile, $5 \%(\mathrm{v} / \mathrm{v})$ trifluroacetic acid] was added and incubated for $1 \mathrm{~h}$ followed by centrifugation at $10,000 \mathrm{~g}$ for one minute. The supernatant containing digested peptides was collected. The gel was extracted again with $50 \mu \mathrm{L}$ elution solution to collect the remaining peptides. The supernatants from the two extractions were pooled together in a new eppendorf and vacuum-dried in SpeedVac for $1 \mathrm{~h}$. The eluent was determined with liquid chromatographymass spectrometry (LC-MS/MS). Proteomic mass spectrometry analyses were performed by the Core Facilities for Protein Structural Analysis located at the Institute of Biological Chemistry, Academia Sinica. MS/MS raw data were processed and searched against a target protein sequence database using the Mascot (http://www. matrixscience.com/). The following search criteria were used: (1) the database was set to be Swiss-Port or NBCInr; (2) taxonomy was set to be green plants; (3) enzyme setting was trypsin; (4) MS/MS tolerance was set to be $0.25 \mathrm{Da}$; (5) data format setting was pkI; (6) instrument was set to be ESI-QUAD. Protein hits with Mascot score $>50$ and $\mathrm{P}$ value $<0.05$ as well as matched molecular weights resolved on the gel were then identified as significant proteins.

\section{RESULTS AND DISCUSSION}

\section{Effects of extraction methods on papaya seed pro- teome analysis}

It has been reported that the papaya seeds are rich in phenolic compounds and p-hydroxybenzoic acid being the major one (Chow and Lin, 1991; Kothari and Seshadri, 2010). To remove these phenolic compounds interfering the efficiency of protein extraction and resolution of $2 \mathrm{D}$ analysis, we have employed both TCA-A and $\mathrm{P}-\mathrm{AA}-\mathrm{M}$ for isolating proteins from papaya seeds, independently. The extracted proteins were analysed 
by $1 \mathrm{D}$ SDS-PAGE. As shown in Fig. 1, the amounts of proteins extracted by $\mathrm{P}-\mathrm{AA}-\mathrm{M}$ method were significantly higher and resulted in at least five more protein bands on SDS-PAGE than those extracted by TCA-A method. These extra bands were resolved with molecular weights at 75, 37, 30, 25, and $20 \mathrm{kDa}$.

The same protein samples were also analysed by $2 \mathrm{D}$ gel electrophoresis with first dimension in $\mathrm{pH}$ 3-10 IPG gel and second dimension in 12.5\% SDS-PAGE. As shown in Fig. 2, the proteins isolated by P-AA-M method (Fig. 2B) revealed much better separation between protein blots and higher resolution than those precipitated by TCA-A method (Fig. 2A), in which serious streaking and smearing were evident on the $2 \mathrm{D}$ gel. Consequently, $\mathrm{P}-\mathrm{AA}-\mathrm{M}$ method was able to resolve $717 \pm 32$ protein spots as compared with only $124 \pm 27$ protein spots were detected from TCA-A method. The result clearly indicated that phenol extraction combined with ammonium acetate/methanol precipitation was a better method than typical TCA/acetone method for papaya seed proteome analysis.

While proteomics plays important roles in research of plant biology and agriculture, not all the organs or cell types were actively investigated at proteome scale.

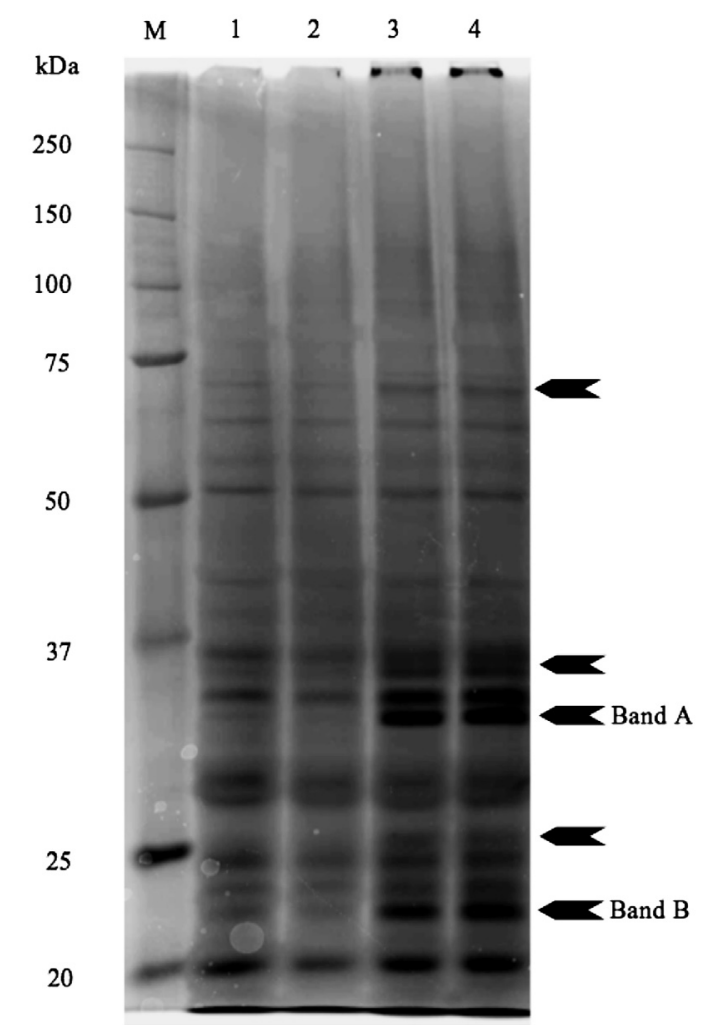

Fig. 1. SDS-PAGE analysis of papaya seed proteins prepared by $10 \%$ trichloroacetic acid (TCA)/acetone precipitation (TCA-A) (lanes 1 and 2) or phenol extraction followed by $0.1 \mathrm{M}$ ammonium/methanol precipitation (P-AA-M) (lane 3 and 4). The arrows indicate the different protein bands between the two extraction methods. Marked band A and band $\mathrm{B}$ are distinct protein bands prepared by P-AA-M. Fifty microgram of protein was loaded per lane. M: molecular weight marker.
In view of the importance of proteomics research in understanding the molecular mechanisms and pathways underlying the papaya seed germination and responses to various environmental signals, we have now established the methodology for protein extraction and 2D gel electrophoresis of papaya seeds. This provides an important platform for further in-depth seed proteomics analysis of papaya or even other plants. In particular, this platform shall be most useful for proteomics study of woody plants or tissues with high contents of secondary metabolites or phenolic compounds,

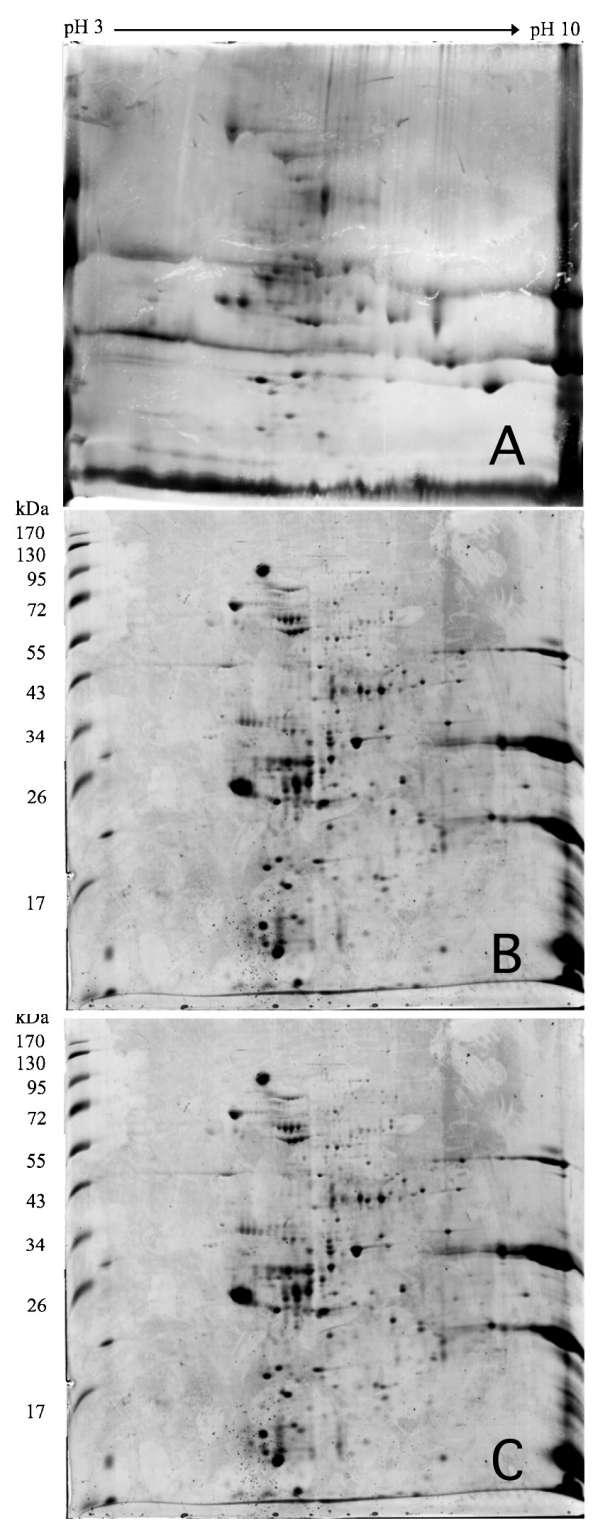

Fig. 2. Two-dimensional profiles of papaya seed proteins extracted by using two different extraction methods and visualized by different staining processes. (A) Proteins were extracted by 10\% trichloroacetic acid / acetone precipitation (TCA-A) and the gel was stained with zinc reversestain. (B) Proteins were extracted by phenol extraction followed by $0.1 \mathrm{M}$ ammonium/methanol precipitation (P-AA-M) and the gel was stained with zinc reverse-stain (C) Proteins were extracted by $\mathrm{P}-\mathrm{AA}-\mathrm{M}$ method and the gel was stained with Coomassie Brilliant Blue R-250. Molecular weight markers were indicated on the left. 
which are the interfering substances that may be not efficiently removed by the typical protein extraction protocol (Wang et al., 2006).

Most popular protein extraction/precipitation method used for plant materials is the utilization of $10 \%$ TCA/acetone for protein precipitation prior to $2 \mathrm{D}$ gel electrophoresis of plant tissues. This method has been widely used in a variety of plant species and tissues including Arabidopsis plantlets (Santoni et al., 1994), rice seeds (Yang et al., 2007), and papaya leaves (Rodrigues et al., 2009). This method has been demonstrated to efficiently remove non-protein macromolecular polymers such as water-soluble cell wall polysaccharides and polyphenols and thereby prevent their interferences on 2D gel electrophoresis (Saravanan and Rose, 2004). However, TCA/acetone precipitation is not sufficient to remove the interferences of papaya seeds and thereby results in significant horizontal and vertical streaking on the 2D gel (Fig. 2A). This poor resolution may be caused by the existence of phenolic compounds that are rich in papaya seeds (Chow and Lin, 1991; Kothari and Seshadri, 2010) but could not be efficiently removed by TCA/acetone precipitation. Even 2\% PVPP was added as the phenol compound adsorbent in the protein extraction buffer we used, no further improvements in the number and resolution of protein spots on $2 \mathrm{D}$ gel electrophoresis could be detected. This result may be caused by the incapability of TCA-A precipitation step in avoiding the co-precipitation of the interfered compositions of papaya seed from its proteins. In contrast, when the buffer-extracted proteins were extracted again by phenol followed by $0.1 \mathrm{M}$ ammonium acetone/methanol mixtures to perform precipitation, the interferences were significantly suppressed. Moreover, since proteins were partitioned into the phenol phase, phenol extraction step could remove most of the water-soluble contaminants and salts. Wang et al. (2006) incorporated phenol extraction process to their extraction protocol and gained protein samples with lower interferences for 2D gel electrophoresis from olive (Olea europaea L.) leaves and fruit, as well as apple (Malus $\times$ domestica Borkh.) fruit. Furthermore, Zheng et al. (2007) pointed out that protein samples of strawberry (Fragaria $\times a n a n a s s a$ Duchesne) fruit prepared by method including phenol extraction step showed more distinguishable protein spots and better resolution on 2D gel profile than the sample without phenol extraction. The success in the use of phenol for protein extraction from cotton (Gossypium hirsutum L.) seed that is rich in polysaccharides, polyphenols, nucleic acids, and secondary metabolites was also demonstrated for reduced background interferences and increased protein spots on 2D gel (Xie et al., 2009). Additionally, the chemical reagents of the P-AA-M method we used did not include any organic acid, thus the $\mathrm{pH}$ of sample was less disturbed during extraction and precipitation processes (Wang et al., 2006) and, as a consequence, minimized the frequency of washing steps as well as prevented interference of IEF electrophoresis.
Comparison of zinc-reverse stain and CBB stain for protein separation and detection on $2 \mathrm{D}$ profile analysis

Two staining methods, zinc-reverse stain and CBB stains, were used to reveal the protein profiles of papaya seeds. We observed seven folds or more of protein spots on zinc-reverse stained gel (Fig. 2B) than CBB-stained gel (Fig. 2C). This result is consistent with higher sensitivity of zinc reverse stains for detecting $1 \mathrm{ng}$ of BSA, as compared with $\mathrm{CBB}$ at sensitivity at $100 \mathrm{ng}^{\text {band }}{ }^{-1}$ (Patton, 2002). Importantly, zinc reverse stains also revealed linear range of sensitivity from 1 to 100ng of BSA, suggesting that this is a sensitive and quantifiable staining method suitable for 2D gel analysis.

CBB with minimal sensitivity 100 ng band $^{-1}$ (Patton, 2002) is routinely used in protein gel staining because of its high reproducibility, simple operation, and wide compatibility for most of proteins. However, proteins accumulated in a low abundant level cannot be visualized via CBB stain, thus silver stain or fluorescent dye SYBRO Ruby with a higher sensitivity are used as a substitute technique (Miller et al., 2006). Despite its high sensitivity (1 ng band ${ }^{-1}$ ) to protein staining, the reproducibility, narrow reliable linear range, and spot intensity highly influenced by the timing of staining procedure are problematic and therefore easily render in an incorrect estimation for silver stained 2D gel when the profile is analyzed (Miller et al., 2006). On the other hand, the sensitivity of SYBRO Ruby is comparable to silver staining. The former displays better reproducibility and reliable linear range than the later. However, the fluorescent dye is expensive and images have to be analysed by the specialized fluorescent machine such as Typhoon Imager (Amersham), thus caused many restrictions. Zinc-reverse stain used in the present study showed comparable in both the time required for staining process and detection sensitivity as compared with other two staining methods. The intensity of protein spots on reverse-stained gel was almost independent from the incubation time of staining. In addition, reverse-stained gel was less likely contaminated by chemicals during the procedure and was feasible for destaining and restaining, which is an advantage that CBB stain and silver stain lack. According to the results we obtained, the profile of reverse-stained $2 \mathrm{D}$ gel showed more distinguishable protein spots than those of CBB-stained one (Fig. 2B and C). The fact that proteins invisible on $\mathrm{CBB}$-stained gels were detected on the zinc-reverse stained gels proves that zinc-reverse staining enhanced sensitivity of protein detection. Moreover, if gel staining was overdone and was not in an optimal situation, zinc-reverse stained gels could be destained and restained again to optimize the staining intensity or restained with $\mathrm{CBB}$ without any obvious interference. In considering its comparable sensitivity and several advantages, zinc-reverse stain may be considered as the most convenient, speedy, and affordable staining method for proteomics study. 


\section{Effect of the pH gradient range of IPG gel strip on the resolution of $2 \mathrm{D}$ profile}

The pH 3-10 IPG gel was initially used for 2D gel electrophoresis (Fig. 2B), which exhibited that the majority of proteins are resolved in the $\mathrm{pH}$ range between 4 and 8 . To further improve the resolution of $2 \mathrm{D}$ gel, the protein samples extracted by $\mathrm{P}-\mathrm{AA}-\mathrm{M}$ method were separated in the $\mathrm{pH} 4-7$ IPG gel prior to SDS-PAGE. The protein profile significantly increased the resolution of protein spots in this $\mathrm{pH}$ range (Fig. 3) when compared to those in pH 3-10 gel (Fig. 2B).

High quality of protein samples is absolutely essential for good result of IEF. The presence of interfering substances, such as nucleic acids and salts, would cause proteins focusing incompletely during electrophoresis, resulting in blurry and distorted 2D gel images (Saravanan and Rose, 2004). Protein samples extracted by $\mathrm{P}-\mathrm{AA}-\mathrm{M}$ method enhanced the resolution of the $2 \mathrm{D}$ gel profile of papaya seeds protein when compared to those by TCA-A protocol (Fig. 2A and B). The protein spots of papaya seeds on $2 \mathrm{D}$ gel were found mainly in the region between $\mathrm{pH} 6$ and $\mathrm{pH}$ 7.5, when a $\mathrm{pH} 3-10$ IPG gel strip was used for IEF electrophoresis (Fig. 2B). We, therefore, further successfully improved the number and resolution of protein spots on $2 \mathrm{D}$ profile by separation in IPG gel at pH 4-7 (Fig. 3). Our data also suggested that the pI values of the water-soluble proteins of papaya seeds were barely resolved in extreme $\mathrm{pH}$ ranges (Fig. $2 \mathrm{~B}$ ). The lower representatives of acidic and alkaline proteins could be due to the technical issue as proteins with extreme acidic or basic pI or hydrophobic characteristics, such as the membrane protein and ribosomal protein are poorly extracted or resolved in IEF. Alternatively, the proteins from papaya seeds may contain less highly acidic or basic proteins. Future

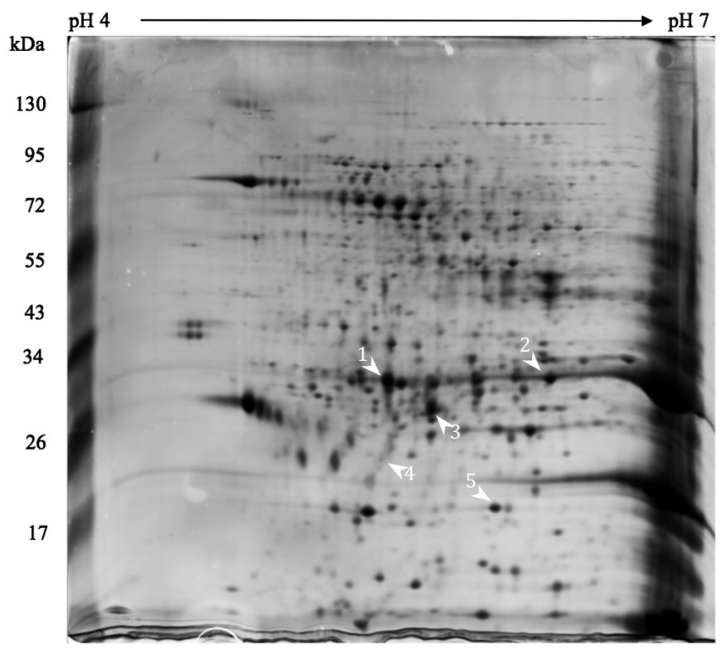

Fig. 3. Two-dimensional gel profile of papaya seed proteins prepared by phenol extraction followed by $0.1 \mathrm{M}$ ammonium/ methanol precipitation ( $\mathrm{P}-\mathrm{AA}-\mathrm{M})$ after first-dimension separation using a $\mathrm{pH}$ 4-7 immobilized $\mathrm{pH}$ gradient (IPG) gel strip and visualized by zinc reverse-staining. Spot numbers corresponding with the numbers in Table 2 are labeled with white arrows pointing to each protein spot. work to use IPG gel with narrow range in acidic or basic $\mathrm{pH}$ may reveal more acidic and basic proteins.

The efficacy of protein separation by IEF was also affected by the amount of proteins loaded. When proteins was over loaded, it spends more time for each protein to move to its isoelectric point; smearing or aggregation of protein samples at a certain region on the $2 \mathrm{D}$ gel was observed especially in case of electrophoresis process was not long enough. We found that the optimal concentration of protein sample for IEF electrophoresis was $1.6 \mu \mathrm{g} \mu \mathrm{L}^{-1}$ (i.e. $800 \mu \mathrm{g}$ proteins in $500 \mu \mathrm{L}$ IPG buffer solution).

\section{Protein identification by LC-MS/MS}

To further compare the differences of extraction efficacy between TCA/A and P-AA-M methods and to examine the compatibility of the $\mathrm{P}-\mathrm{AA}-\mathrm{M}$ method with LC-MS/MS analysis, two outstanding 30- (Band A) and 20-kDa (Band B) protein bands on the SDS-PAGE analysis (Fig. 1) were chosen for protein identifications by LC-MS/MS. A total of eight and five of proteins were identified from 30-kDa (Band A) and 20-kDa (Band B) bands, respectively, as significant hits (Table 1). For the $2 \mathrm{D}$ gel analysis, five protein spots were selected for protein identification (Table 1).

Although 15 of proteins isolated from papaya seeds were identified from selected protein bands and spots, only two proteins, namely small GTP-binding protein (Table 1) and $17.5 \mathrm{kDa}$ class I heat shock protein (Table 1), matched the papaya protein database whereas other proteins were identified by matching with the orthologous proteins encoded in other green plants (Table 1). Similar observation was also reported in the proteomics analysis of papaya leaves, in which only a few proteins were identified from papaya protein database (Rodrigues et al. 2009). These results indicated that papaya genome has been completed, but the protein database is barely annotated for protein identifications by MS/MS ions.

In conclusion, we have clearly demonstrated that protein samples of papaya seeds, a high phenolics-contained plant material, prepared by the P-AA-M method included more protein spots and less contaminants than traditional TCA/A protocol via SDS-PAGE and 2D gel analysis. Smearing and streaking problems occurred on the 2D gel profile of TCA/A-extracted samples were markedly suppressed when P-AA-M-prepared samples utilized. The protein number and resolution on $2 \mathrm{D}$ gel profile were further improved by incorporation of $\mathrm{pH}$ 4-10 IPG gel strip for IEF electrophoresis and zincreverse stain technique. The protein samples of papaya seeds isolated from the protocol we established were compatible with LC-MS/MS analysis. The high-resolution 2D map with identifications of several proteins from papaya seeds shall serve as a platform and reference for future research in seed biology of papaya or other plants.

\section{REFERENCES}

Andreoli, C. and A. A. Khan 1993 Improving papaya seedling emergence by matriconditioning and gibberellins treatment. 
Table 1. Identifications of the distinct protein bands (bands A and B seen in Fig. 1) prepared by phenol extraction followed by $0.1 \mathrm{M}$ ammonium/methanol precipitation (P-AA-M), those prepared by 10\% trichloroacetic acid / acetone precipitation (TCA-A) in SDSPAGE analysis and protein spots from 2D gel analysis. The proteins were identified by LC-MS/MS

\begin{tabular}{|c|c|c|c|c|c|c|}
\hline Putative protein & Accession No. & Organism & $\begin{array}{l}\text { Calculated } \\
\text { MW } \\
(\mathrm{kDa}) / \mathrm{pI}\end{array}$ & Peptide sequence hit & $\begin{array}{l}\text { Sequence } \\
\text { coverage } \\
(\%)\end{array}$ & $\begin{array}{r}\text { Protein } \\
\text { scores }\end{array}$ \\
\hline \multicolumn{7}{|l|}{ SDS-PAGE } \\
\hline \multicolumn{7}{|l|}{ Band A } \\
\hline Malate dehydrogenase & P19446 & Citrullus lanatus & $37.6 / 8.67$ & $\begin{array}{l}\text { RGFLGQQQLEAALTGMDLIIVPAGVPRK; } \\
\text { RAIVNLISNPVNSTVPIAAEVFKK; } \\
\text { RAIVNLISNPVNSTVPIAAEVFKKA; } \\
\text { KRLLGVTMLDVVRA; } \\
\text { RLLGVTMLDVVRA }\end{array}$ & 17 & 199 \\
\hline Hypothetical protein & XP_002273346 & Vitis vinifera & $33.1 / 5.50$ & $\begin{array}{l}\text { KTVLVDNEDFLKE; } \\
\text { KITRQPGPIPGLNTKI; } \\
\text { KGNAYAQVAISTDDVYKS }\end{array}$ & 14 & 140 \\
\hline $\begin{array}{l}\text { Rubber elongation factor } \\
\text { protein }\end{array}$ & $\mathrm{P} 15252$ & Heveabra siliensis & $14.7 / 5.04$ & $\begin{array}{l}\text { KSGPLQPGVDIIEGPVKN; } \\
\text { KNVAVPLYNRF; } \\
\text { KDASIQVVSAIRA }\end{array}$ & 26 & 96 \\
\hline $\begin{array}{l}\text { Putative uncharacterized } \\
\text { protein }\end{array}$ & ACJ85383 & Medicago truncatula & $31.5 / 7.06$ & $\begin{array}{l}\text { KVPGLAVVIVGNRQ; } \\
\text { RSNIVGLPVLLLLKA; } \\
\text { KVAGWITPVPGGVGPMTVTMLLKN }\end{array}$ & 16 & 66 \\
\hline $\begin{array}{l}\text { Glucose and ribitol } \\
\text { dehydrogenase homolog } 1\end{array}$ & AAG51119 & Arabidopsis thaliana & $31.2 / 5.92$ & $\begin{array}{l}\text { RVVDEVVNAFGRI; } \\
\text { KRVVDEVVNAFGRI; } \\
\text { KRVVDEVVNAFGRI }\end{array}$ & 4 & 59 \\
\hline Cytosolic cysteine synthase & BAB20861 & Solanum tuberosum & $34.3 / 5.93$ & $\begin{array}{l}\text { RAFGAELVLTDPAKG; } \\
\text { KLIITMPSSMSLERR }\end{array}$ & 8 & 54 \\
\hline $\begin{array}{l}\text { Putative uncharacterized } \\
\text { protein }\end{array}$ & XP_002894087 & Arabidopsis lyrata & $34.3 / 8.77$ & $\begin{array}{l}\text { MAITKERR; } \\
\text { RTPEEILRI }\end{array}$ & 4 & 47 \\
\hline $\begin{array}{l}\text { Putative NADPH } \\
\text { dependent mannose } \\
6 \text {-phosphate reductase }\end{array}$ & NP_179721 & Arabidopsis thaliana & $35.0 / 6.16$ & $\begin{array}{l}\text { KTVAQVVLRW; } \\
\text { RDLILNAIKI }\end{array}$ & 5 & 41 \\
\hline \multicolumn{7}{|l|}{ Band B } \\
\hline RAB1C & CAA98160 & Lotus japonicus & $22.6 / 5.30$ & $\begin{array}{l}\text { KLLLIGDSGVGKS; } \\
\text { KNATNVEQAFMAMAAEIKN; } \\
\text { KNATNVEQAFMAMAAEIKN; } \\
\text { RFADDSYLDSYISTIGVDFKI }\end{array}$ & 23 & 152 \\
\hline Ras-related protein RIC2 & BAA02904 & Oryza sativa & $24.0 / 5.37$ & $\begin{array}{l}\text { RAITSAYYRG; } \\
\text { KSTIGVEFATRS; } \\
\text { RGAVGALLVYDVTRH }\end{array}$ & 14 & 68 \\
\hline Predicted protein & XP_002299359 & Populus trichocarpa & $18.7 / 5.07$ & $\begin{array}{l}\text { RNFNIIQHQLGKL; } \\
\text { RNFNIIQHQLGKL }\end{array}$ & 6 & 63 \\
\hline Small GTP-binding protein & BAA88497 & Carica papaya & $23.3 / 8.43$ & $\begin{array}{l}\text { KTVAQVVLRW; } \\
\text { RDLILNAIKI }\end{array}$ & 17 & 51 \\
\hline \multicolumn{7}{|l|}{ 2D-gel } \\
\hline \multicolumn{7}{|l|}{ Spot 4} \\
\hline $\begin{array}{l}17.5 \mathrm{kDa} \text { class I heat shock } \\
\text { protein }\end{array}$ & AAG51119 & Carica papaya & $17.47 / 5.31$ & $\begin{array}{l}\text { DFPFPSSSISR; } \\
\text { VELEDDRVLQISGER; } \\
\text { ASMEN GVLTVTVPK }\end{array}$ & 25 & 191 \\
\hline \multicolumn{7}{|l|}{ Spot 5} \\
\hline $\begin{array}{l}\text { Late embryogenesis } \\
\text { abundant protein }\end{array}$ & $\mathrm{AAB} 01563$ & Picea glauca & $22.47 / 6.22$ & AELSQVKR & 4 & 59 \\
\hline
\end{tabular}

Hortscience, 28: 708-709

Bhattacharya, J. and S. S. Khuspe 2001 In vitro and in vivo germination of papaya (Carica papaya L.) seeds. Sci. Hort., 91: 39-49

Bradford, M. M. 1976 A rapid and sensitive method for the quantitation of microgram quantities of protein utilizing the principle of protein-dye binding. Anal. Biochem., 72: 248-254

Carpentier, S. C., E. Witters, K. Laukens, P. Deckers, R. Swennen and B. Panis 2005 Preparation of protein extracts from recalcitrant plant tissues: An evaluation of different methods for two-dimensional gel electrophoresis analysis. Proteomics, 5:
2497-2507

Chacko, E. K. and R. N. Singh 1966 The effect of gibberellic acid on the germination of papaya seeds and subsequent seedling growth. Trop. Agri. Trin., 43: 341-346

Chow, Y. J. and C. H. Lin 1991 p-Hydroxybenzoic acid as the major phenolic germination inhibitor of papaya seed. Seed Sci. \& Technol., 19: 167-174

Fernandez-Patron, C., M. Calero, P. R. Collazo, J. R. Garcia, J. Madrazo, A. Musacchio, F. Soriano, R. Estrada, R. Frank, L. R. Castellanosserra and E. Mendez 1995 Protein reverse staining: high-efficiency microanalysis of unmodified proteins 
detected on electrophoresis gels. Anal. Biochem., 224:203211

Görg, A. 2000 Advances in 2D gel techniques. Trends in Biotechnol., 18: supplement 13-16

Görg, A., C. Obermaier, G. Boguth, A. Csordas, J. J. Diaz and J. J. Madjar 1997 Very alkaline immobilized pH gradients for twodimensional electrophoresis of ribosomal and nuclear proteins. Electrophoresis, 18: 328-337

Hellman, U., C. Wernstedt, J. Gonezand and C. H. Heldin 1995 Improvement of an "In-Gel" digestion procedure for the micropreparation of internal protein fragments for amino acid sequencing. Anal. Biochem., 224: 451-455

Hurkman, W. J. and C. K. Tanaka 1986 Solubilization of plant membrane proteins for analysis by two-dimensional gel electrophoresis. Plant Physiol., 81: 802-806

Kothari, V. and S. Seshadri 2010 Antioxidant activity of seed extracts of Annona squamosa and Carica papaya. Nutr. \& Food Sci., 40: 403-408

Laemmli, U. K. 1970 Cleavage of structural proteins during the assembly of the head of bacteriophage T4. Nature, 227: 680685

Miernyk, J. A. and M. Hajduch 2011 Seed proteomics. J. Proteomics, 74: 389-400

Mijnsbrugge, K. V., H. Meyermans, M. Van Montagu, G. Bauw and W. Boerjan 2000 Wood formation in poplar: identification, characterization, and seasonal variation of xylem proteins. Planta, 210: 589-598

Ming, R., S. Hou, Y. Feng, Q. Yu, A. Dionne-Laporte, J. H. Saw, P. Senin, W. Wang, B. V. Ly, K. L. Lewis, S. L. Salzberg, L. Feng, M. R. Jones, R. L. Skelton, J. E. Murray, C. Chen, W. Qian, J. Shen, P. Du, M. Eustice, E. Tong, H. Tang, E. Lyons, R. E. Paull, T. P. Michael, K. Wall, D. W. Rice, H. Albert, M. L. Wang, Y. J. Zhu, M. Schatz, N. Nagarajan, R. A. Acob, P. Guan, A. Blas, C. M. Wai, C. M. Ackerman, Y. Ren, C. Liu, J. Wang, J. Wang, J. K. Na, E. V. Shakirov, B. Haas, J. Thimmapuram, D. Nelson, X. Wang, J. E. Bowers, A. R. Gschwend, A. L. Delcher, R. Singh , J. Y. Suzuki, S. Tripathi, K. Neupane, H. Wei, B. Irikura, M. Paidi, N. Jiang, W. Zhang, G. Presting, A. Windsor, R. NavajasPerez, M. J. Torres, F. A. Feltus, B. Porter, Y. Li, A. M. Burroughs, M. C. Luo, L. Liu, D. A. Christopher, S. M. Mount, P. H. Moore, T. Sugimura, J. Jiang, M. A. Schuler, V. Friedman, T. Mitchell-Olds , D. E. Shippen, C. W. dePamphilis, J. D. Palmer, M. Freeling, A. H. Paterson, D. Gonsalves , L. Wang and M. Alam 2008 The draft genome of the transgenic tropical fruit tree papaya (Carica papaya Linnaeus). Nature, 452: $991-997$

Neuhoff, V., N. Arold, D. Taube and W. Ehrhardt 1988 Improved staining of proteins in polyacrylamide gels including isoelectric focusing gels with clear background at nanogram sensitivity using Coomassie Brilliant Blue G-250 and R-250. Electrophoresis, 9: 255-262

Patton, W. F. 2002 Detection technologies in proteome analysis. J. Chromatogr. B Analyt. Technol. Biomed. Life Sci., 771: 3-31

Paull, R. E. and O. Duarte 2011 Papaya. In "Tropical Fruits", Vol.1 ( $2^{\text {nd }}$ ed.), eds. by R. E. Paull, and O. Duarte, CABI, Oxfordshire, pp. 291-326

Rodrigues, S. P., J. A. Ventura, R. B. Zingali and P. M. B. Fernandes 2009 Evaluation of sample preparation methods for the analysis of papaya leaf proteins through two-dimensional gel electrophoresis. Phytochem. Anal., 20: 456-464

Salomao, A. N. and R. C. Mundim 2000 Germination of papaya seed in response to desiccation, exposure to subzero temperatures, and gibberellic acid. HortScience, 35: 904-906

Saravanan, R. S. and J. K. C. Rose 2004 A critical evaluation of sample extraction techniques for enhanced proteomic analysis of recalcitrant plant tissues. Proteomics, 4: 2522-2532

Singh, S. P. and D. V. Sudhakar 2011 Papaya (Carica papaya L.) In "Postharvest Biology and Technology of Tropical and Subtropical Fruits", Vol. 4: Mangosteen to White Sapote, ed. by E. M. Yahia, Woodhead Publishing, Oxiford, pp. 86-124

Wang, W., M. Scali, R. Vignani, A. Spadafora, E. Sensi, S. Mazzuca and M. Cresti 2003 Protein extraction for two-dimensional electrophoresis from olive leaf, a plant tissue containing high levels of interfering compounds. Electrophoresis, 24: 23692375

Wang, W., R. Vignani, M. Scali and M. Cresti 2006 A universal and rapid protocol for protein extraction from recalcitrant plant tissues for proteomic analysis. Electrophoresis, 27: 2782-2786

Wood, C. B., H. W. Pritchard and D. Amritphale 2000 Desiccationinduced dormancy in papaya (Carica papaya L.) seeds is alleviated by heat shock. Seed Sci. Res., 10: 135-145

Xie, C., D. Wang and X. Yang 2009 Protein extraction methods compatible with proteomic analysis for cotton seedling. Crop Sci., 49: 395-402

Yang, P., X. Li, X. Wang, H. Chen, F. Chen and S. Shen 2007 Proteomics analysis of rice (Oryza sativa) seeds during germination. Proteomics, 7: 3358-3368

Zheng, Q., J. Song, K. Doncaster, E. Rowland and D. M. Byers 2007 Qualitative and quantitative evaluation of protein extraction protocols for apple and strawberry fruit suitable for twodimensional electrophoresis and mass spectrometry analysis. J. Agric. Food Chem., 55: 1663-1673 